
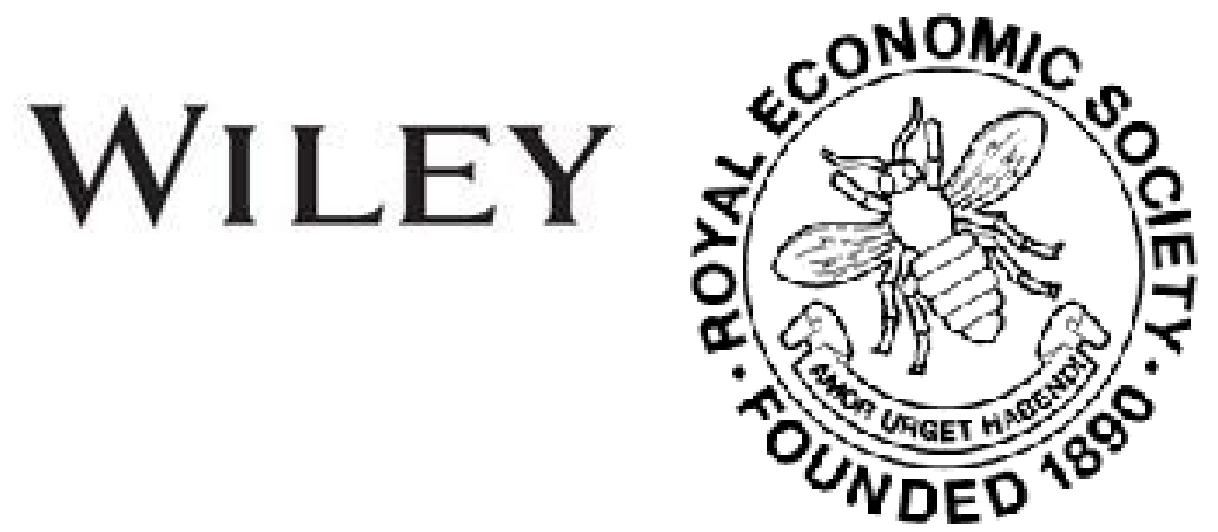

Japanese Finance and Economy

Author(s): Jiuchi Soyeda

Source: The Economic Journal, Vol. 11, No. 43 (Sep., 1901), pp. 435-446

Published by: Wiley on behalf of the Royal Economic Society

Stable URL: http://www.jstor.org/stable/2956682

Accessed: 26-06-2016 23:34 UTC

Your use of the JSTOR archive indicates your acceptance of the Terms \& Conditions of Use, available at

http://about.jstor.org/terms

JSTOR is a not-for-profit service that helps scholars, researchers, and students discover, use, and build upon a wide range of content in a trusted digital archive. We use information technology and tools to increase productivity and facilitate new forms of scholarship. For more information about JSTOR, please contact support@jstor.org.

Wiley, Royal Economic Society are collaborating with JSTOR to digitize, preserve and extend access to The Economic Journal 
The revenue and expenditure of the court and provincial organisations are not included in the above table.

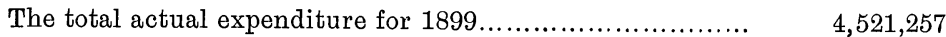

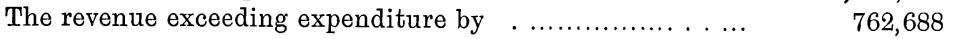

E. Cazalet

\section{Japanese Finance and Economy}

\section{General Remarks.}

AFTER the successful issue of the war with China, the nation was involved in so-called "post bellum enterprises," both on the side of the Government and the people. At first everything seemed to prosper, and nothing was left untouched. The financial and economic questions attained paramount importance. Many a time cabinets changed,'parliaments were dissolved, and finance ministers were altered. ${ }^{1}$ Too rapid expansion is now having its effect. Remedial and retrogressive measures are now the topics of the day. Both statesmen and business people are bothering their heads how to make good the result. Now let us briefly see the course of events from the close of the war with China in March, 1895, up to the present time, viz. May, 1901.

\section{Expenditures and Revenues.}

Before the war the Budget averaged about 80,000,000 yen (yen about one-tenth of a $£$ ); but from 1896 to 1897, the expenditure suddenly rose to $193,435,716$ yen from $85,000,000$ of the previous year, the chief causes of the increase being the expansion of the military and naval armaments, establishment of Kioto University, carrying out of river works scheme, colonization of Hokkaido, improvement of railways and extension of telephone service, establishments of agricultural experiment and silk-worm culture offices, encouragement of trade, and establishments of exhibition rooms and iron foundry. From the above it is clear that the Government did not neglect the development of the country's resources, although much stress was laid on the perfection of the means of defence. The ordinary revenue of this year being only $100,700,000$ yen, the deficit stood at $92,640,000$. It was covered by the fund transferred from the extraordinary war fund, the revenue from Formosa, the indemnity paid by China, public loan and sur-

1 Count Matsukata (March, 1895, to August, 1895), Viscount Watanabe (August, 1895, to September, 1896), Count Matsukata (September, 1896, to January, 1898), Count Inouye (January, 1898, to July, 1898), Mr. Matsuda (July, 1898, to November, 1898), Count Matsukata (November, 1898, to September, 1900), and lastly, Viscount Watanabe (September, 1900).

G G 2 
plus fund of the preceding year, and the increased taxation, such as registration tax, profession tax, saki tax, monopoly of leaf-tobacco, although it was the first item only which came into force in this year.

In the Budget for 1897-98 the expenditure rose to $249,547,285$ yen, embodying in itself the expenses for the armament expansion of the second period, the Hokkaido railways, for the Kioto University, for the carrying out the leaf-tobacco monopoly, for the establishment of new legations and consulates, and for the improvement of customs services. The revenue was estimated at 249,524,670 yen, and the deficit was to be met with the surplus fund of the preceding year and the Chinese indemnity.

The Budget for 1898-99 was drawn up with 212,114,119 yen as receipts, and $233,723,708$ yen as expenditure. But this did not become an actuality on account of the dissolution of the Parliament, and the Budget of the previous year was carried out according to the provision in our Constitution. Thus, the scheme to increase the rates of land and saki taxes fell through, causing the deficit of 20,616,178 yen in the supplementary Budget, which compelled the Government to make use of the Chinese indemnity and temporary loans. In order to avoid a large deficit in the coming fiscal year, another attempt was made to increase taxes, but it met with the same unfortunate fate as before. In the Budget for 1899-1900, the revenue stood at 246,953,074 yen, while the expenditure stood at 246,451,706 yen, leaving a surplus of 501,368 yen. But, owing to the repeated failure of the scheme of increasing taxation, there was a possibility of about $37,000,000$ deficit being ultimately inevitable. This compelled the Finance Minister to bring forward a new scheme aiming at an additional revenue of about $42,000,000$ yen from taxes on land, income, saki, registration, soy, the Bank of Japan, as well as from tonnage dues, and the monopoly of leaftobacco and the post and telegraph services. The gap was filled again by borrowing from the indemnity fund. As the first scheme of increased taxes aimed at obtaining $33,576,000$ yen, the total increase of taxes intended came up to about 75,000,000 yen.

The Budget for 1900-1901 set forth 254,549,818 yen as receipts, and $254,549,817$ yen as expenditure. Thus, by the coming into force of the increased tax laws, incomings and outgoings were nearly equalized, making firmer the basis of the national finance. The important items in expenditure are expenses for legations and concessions, for Statemaintenance of prisons, for river works, for education, railways, and customs services, as well as for subsidy to local waterworks and navigation companies.

In the Budget for 1901-1902, the receipts are estimated at $277,497,000$ yen, and expenditure at $275,887,000$ yen, thus leaving a surplus of 1,609,000 yen. The chief items of the increased expenditure are the expenses related to the Boxers' affair, and to the iron foundry, telephone, prisons, etc. In order to meet expenditure, an increase of $6,293,575$ yen is expected to be obtained from the enhanced rate of 
saki tax, customs, and leaf-tobacco monopoly, as well as from the sugar and beer tax. By 1903-1904, the full amount of over 20,000,000 is expected from the taxation. Thus the third scheme of increased taxation, with $75,000,000$ yen of the first and the second, will give the result of little over $90,000,000$ yen as the total of the increased taxation. However, until the whole amount is realized, loans are to be resorted to. This state of affairs gave rise to the difference of views between those who advocate the negative policy of stopping works which can be delayed, and those who uphold positive views of pushing on.

\section{Special Comptabilité.}

Besides, there are 32 special comptabilités whose accounts are kept apart from general receipts and expenditures. They will be passed over on account of much complexity, and of less importance, except the Formosan administration, Chinese indemnity, and the War-vessels Funds.

In 1897-98 a special comptabilité was established for Formosa, with the view of gradually decreasing the amount of the deficit filled up from the Home Government by the practice of economy in expenditures on the one hand, and on the other by increasing the revenue of the island. This self-supporting scheme has been beneficial to both the new colony and the mother country, and the subsidy by the latter, which was 6,000,000 yen in 1898-99, is on the decrease, and will cease altogether in 1910-11. In the Budget for 1899-1900, 35,000,000 yen were granted to be issued as national debt, and to be devoted chiefly to the construction and improvement of railways and harbour works of the island. By the way, a hopeful future lies before the island, productive power being larger than expected. Besides sugar, tea, camphor, and rice, she abounds in minerals, and if well managed and explored thoroughly, she may be a treasure to Japan.

The total sum received from China as indemnity comes up to $365,529,067$ yen. But they were not sent over at once to Japan, in order to avoid disturbances in the money market, but were transmitted sometimes by means of exchange operations and sometimes by the shipment of bullion. At one time the Government transformed the debt into securities, or deposited it in the hands of the London agency of the Bank of Japan, borrowing from the latter a corresponding amount of convertible notes at home. At last it became expedient to establish a separate comptabilité for this fund, and it was so carried out by a law passed in March, 1896. The way in which the indemnity fund was spent concerns chiefly the military and naval expansion. But some part was devoted to economic uses, such as debentures of the Industrial Bank of Japan, to the amount of $3,639,960$ yen, when it was deemed necessary to relieve the money market in 1897 and 1898. Besides, some portions of the fund were invested in Treasury bills in London, some were used in giving facilities to exchange operations, and some were utilised to cover expenditure for a time. As permanent 
measures, out of the indemnity 30,000,000 yen were set apart as the War-vessels, Torpedo-boats, Replenishing Fund, 10,000,000 yen as the Education Fund, and another $10,000,000$ yen as the Calamities Reserve Fund. The half of the first fund is to be kept in gold in order to meet the contingency with promptitude. It is true that the gold was borrowed for a time from the fund in order to carry out the new standard. But the silver obtained by the conversion of one-yen coins was sold, and with this proceed the debt to the fund was paid back. So it cannot be said that the new standard encroached on the indemnity fund.

\section{National Debt.}

At the close of 1897-98 the Government was confronted with the necessity of issuing about 262,398,000 yen of public debt, mostly for the construction of railways. But owing to the stringency of the money market, no more than 56,807,350 could be issued, and even this was mostly supplied from the deposits entrusted to the Treasury and the Chinese indemnity fund. In 1898-99 the stringency continued, so the estimated amount to be issued in this year, $79,292,028$ yen, could not be realized, and the Chinese indemnity was temporarily made use of. In 1899-1900, the Finance Minister was placed under the necessity of issuing 100,258,889 yen, but still the state of the money market did not allow its realization. It was decided to issue loans abroad, and a bill was passed in 1899, and $£ 10,000,000$ sterling was raised in London at 4 per cent. in June of the same year. But still 107,960,993 yen remained to be issued for the Imperial Treasury, and 35,000,000 yen more for Formosan public works. The stringency continues still, so the country is now placed in a dilemma between issuing loans abroad, or stopping for a time the progress of various Government works contemplated. In case it is decided to invite subscribers abroad, foreign capitalists need not be apprehensive in the least, because the money so imported is to be spent mostly on railways and other profitable purposes.

Let us see how the figures stand for the last ten years.

\begin{tabular}{|c|c|c|c|c|}
\hline Year. & Amount issued. & Amount redeemed. & Amount unredeemed. & $\begin{array}{c}\text { Amount per } \\
\text { head. }\end{array}$ \\
\hline & Yen. & Yen. & Yen. & Yen. \\
1891 & $25,347,450$ & $10,163,996$ & $275,236,669$ & $6 \cdot 804$ \\
1892 & $19,462,450$ & $20,073,110$ & $274,626,009$ & 6744 \\
1893 & $40,850,350$ & $37,582,047$ & $277,894,311$ & $6 \cdot 763$ \\
$\mathbf{1 8 9 4}$ & $18,987,100$ & $30,068,360$ & $266,814,851$ & $6 \cdot 447$ \\
1895 & $32,500,000$ & $16,078,798$ & $283,236,053$ & $6 \cdot 774$ \\
1896 & $144,234,000$ & $35,356,158$ & $392,113,895$ & $9 \cdot 276$ \\
1897 & $105,928,875$ & $70,920,835$ & $427,121,934$ & 10001 \\
1898 & $57,453,378$ & $72,761,052$ & $411,784,260$ & $9 \cdot 526$ \\
1899 & $61,123,350$ & $56,625,736$ & $413,281,873$ & $9 \cdot 446$ \\
1900 & $100,365,750$ & $10,446,974$ & $503,200,649$ & $11 \cdot 501$ \\
& & & & \\
\hline
\end{tabular}


From the above table it is clear that Japan is not yet too much in debt, and that she has been eager to pay back her debt. Moreover, debts owed by her to foreign countries are $£ 10,000,000$ sterling and a small amount $(£ 4,300,000)$ issued for the war loan. According to the financial scheme already fixed, her debt is to be totally redeemed in the course of fifty years. Even granting that circumstances may change, and some alteration of this scheme may become necessary, her capacity is ample enough to pay off liabilities, provided her finance be well managed. Her present difficulty, if it should be so called, is not serious.

\section{Banking.}

In order to make convertible the paper currency of Japan, the National Banks were ordered to give up their privilege of issue at the expiration of their term or at their option, and to redeem their notes with those issued by the Bank of Japan, which are convertible into gold. By 1899 all of them were changed into ordinary banks and their notes ceased to circulate. ${ }^{1}$ The Government then began to work for central and local industrial banks in order to give facilities to agriculture and industry, as well as to turn the money spent for post bellum enterprises into useful channels by means of the debentures issued by these banks.

The laws for these banks were passed in 1896, and the Central Industrial Bank was opened in June, 1897, with a capital of 10,000,000, its quarter being paid up for the time. This bank being established for public benefit and not allowed to charge high interest, its profits. were small at first, and the Government paid subsidies in order to enable the bank to pay 5 per cent. dividend. But since June, 1899, the bank commenced to pay dividends of $6 \frac{1}{2}$ per cent., and was able to pay 9 per cent. for the term ending December 1900. In 1898, when the cotton mills in Osaka were in great need of capital, debentures of this bank were purchased by the Government, and the money was supplied to them. This was a great stimulus to textile industry, and since then the bank is doing a tolerably good business, as is clear from the following figures :-

Yen.

Debentures outstanding in March, $1901 \ldots \ldots \ldots \ldots$ 10,622,140

Loans $\quad, \quad \quad, \quad, \quad \ldots \ldots \ldots \ldots . \quad 12,213,970$

Out of this lent to public bodies .................. 2,409,392

" $\quad$ " agriculturists ................. $3,761,348$

", ", manufacturers $\ldots \ldots \ldots \ldots \ldots \ldots . .6,043,229$

The Local Industrial Banks were not opened at the same time with the central institution, on account of the work of organization being entrusted to local authorities. But by December, 1899, every prefecture (45 in all) had an Industrial Bank. Their capital in all amounts to $27,920,000$ yen $(24,176,000$ yen paid up), of which about $8,028,000$

1 By April, 1901, only 467,336 yen remained unredeemed out of $34,396,880$ yen. 
(actually paid $7,402,574$ ) yen are supplied by the Government to the prefect in order to enable him to become a shareholder, to receive no dividends for five years. Although the debentures issued by them do not fare so well as those of the Central Bank, on account of their not being allowed to pay lottery premiums, yet their giving benefit to small farmers and artisans must not be overlooked. The figures thus stand :-

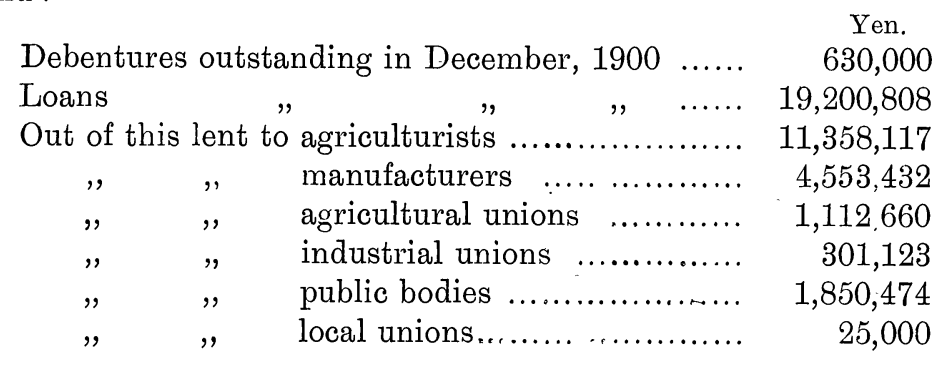

Since the acquisition of Formosa, the Japanese Government has not failed to develop the economy of the island, though there was much to be done in quieting oppositions and riots. As for the currency of the island, it was decided to allow the use of silver yen pieces, although, legally, gold is the standard; and as there was no powerful banking institution, the Government decided to establish something like a central bank for the island, after the pattern of the Bank of Japan, endowed with the power of issuing notes convertible in silver yen. The law for the Bank of Taiwan (Formosa) was promulgated in March, 1897. But the state of market not being favourable for the call of its shares, the actual setting up was delayed. But by March, 1899, various enactments were passed empowering the Government to lend the bank without interest 2,000,000 yen in silver, and to subscribe 1,000,000 yen worth of the bank shares. By June, 1899, the Bank of Taiwan was established with the capital of 5,000,000 yen, its quarter being paid in, and began its business by September of the same year. Now the bank has become an indispensable financial organ of the island, as the figures for December, 1900, give evident proofs :--

$$
\begin{aligned}
& \text { Amount lent out to the Colonial Government ..... } \quad 6,200,000 \\
& \text {," }, \quad " \quad \text { public...................... 1,471,711 } \\
& \text { " deposited..................................... } 4,973,079 \\
& , \quad \text { of notes issued } \ldots \ldots \ldots \ldots \ldots \ldots \ldots \ldots \ldots \ldots, \quad 3,690,871
\end{aligned}
$$

It establishes branch offices in Kobe, Amoy, and various places in the island, besides entering into correspondence with the chief centres of commerce both in the West and East, and 8 per cent. was paid as dividend for the half year ending December, 1900.

The northern island, Hokkaido, was also supplied with a colonial bank by a law passed in March, 1899. The system is much like the bank in Algeria, and aims at the giving loing and cheap loans, mostly to 
agricultural undertakings. It is also empowered to issue debentures, and is subsidized by the Government.

The loans outstanding in March, 1901, are 802,195 yen, the particulärs being :-

Yen.

Instalment loans ................................ 704,557

Fixed period loans .............................. 67,040

Loans against securities .......................... 24,805

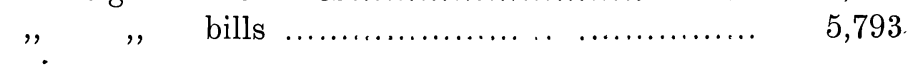

Another institution was found necessary to give facilities for the negotiation of shares and stocks. A bill for the Japan Credit Mobilier was presented to the Parliament in 1900. The House added a clause by which the Government may endorse in case the debentures are issued in foreign countries. Owing to the ministerial changes and to the state of the money market, the establishment is put off for the present.

Since the war, a number of banks have made a rapid increase. The figures stood thus by the end of March, 1901 :-

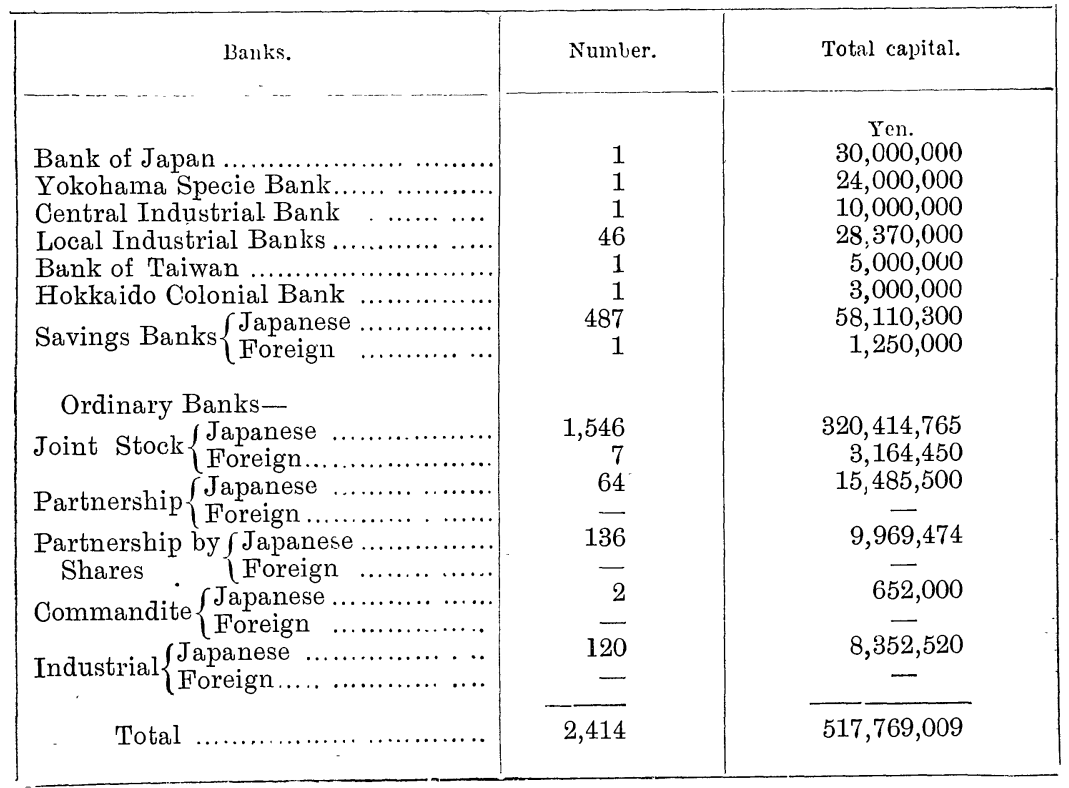

It needs no argument that savings banks must be under strict control of the State in order to avoid abuses and to protect the deposits of the lower classes. The actual law being too lenient, a bill to revise it was presented in the Parliament before last, but the House adjourned ere it was pass ad. Early in 1901 a bill was prepared to be presented to the last Parliament, but it was postponed. The " run" began in some banks in Kiushiu, Osaka, Kioto, and Nara, but things have not 
become so serious as to be called a panic, especially by the timely help given by the Bank of Japan. In connection with this, a few remarks will be added about the Bank of Japan.

Since the increase of its capital to $30,000,000$ yen in February, 1898, its sphere of operation has been much increased. By laws promulgated in March, 1899, the limit of note-issue on the documentary reserve was increased from $85,000,000$ to $120,000,000$ yen, and at the same time the Bank was obliged to pay as tax a part of its profits accruing from its note-issue to the State. Out of the increase of $35,000,000$ yen, $15,000,000$ yen was intended to be devoted towards discount of commercial bills at home, and the rest $(20,000,000)$ towards commercial uses abroad, chiefly through the mechanism of the Yokohama Specie Bank.

Although much remains to be improved in the banking system, and careful discrimination must be exercised by them, yet their activity is fast increasing at the same time. For instance, bills cleared in Tokio and Osaka clearing houses were $252,000,000$ yen in 1893, and $705,000,000$ yen in 1896, but rose to $1,929,000,000$ yen in 1900 .

\section{Currency and Prices.}

While Japan remained a de facto silver standard country, the fall of the white metal troubled her both in finance and general economy. The Chinese indemnity gave her the opportunity of changing the standard into gold, as the sum was paid in the yellow metal. The New Coinage Act was made public in March, 1897, by which the gold standard came into force in October of the same year, and the free coinage of silver was done away with. One-yen silver coins were converted between October, 1897, and July, 1898, to the amount of $45,588,369$ yen, besides $29,505,453$ of silver coinage notes issued by the Mint. This may appear too small when compared with $165,133,710$ yen, the total amount issued. But nearly 100,000,000 out of the total issue were exported, mostly to China, where they are inevitably chopped and deprived of the form of currency.

Of 75,093,822 converted, most part were sold in exchange for gold, a part were transformed into subsidiary coins, and the rest sent to Formosa, Korea, \&c., without any loss on the whole. As to the result of the change of the standard, many conflicting views are entertained. But it has been beneficial on the whole; it is a most mistaken view to assign to the gold standard the increase of the imports and the consequent efflux of gold. The excess of imports would have been much greater if we had clung to the silver standard, through the fall of silver and the consequent rise of prices. Prices, of course, rose a great deal, but this has been chiefly caused by the increase of consumptive power both on the part of the Government and the people since the war.

As is evident from the following table, the exchange with the gold countries was freed from previous fluctuation, while the trade with 
them was increased. Neither was the trade with silver countries hampered as was feared by many opponents of the gold standard.

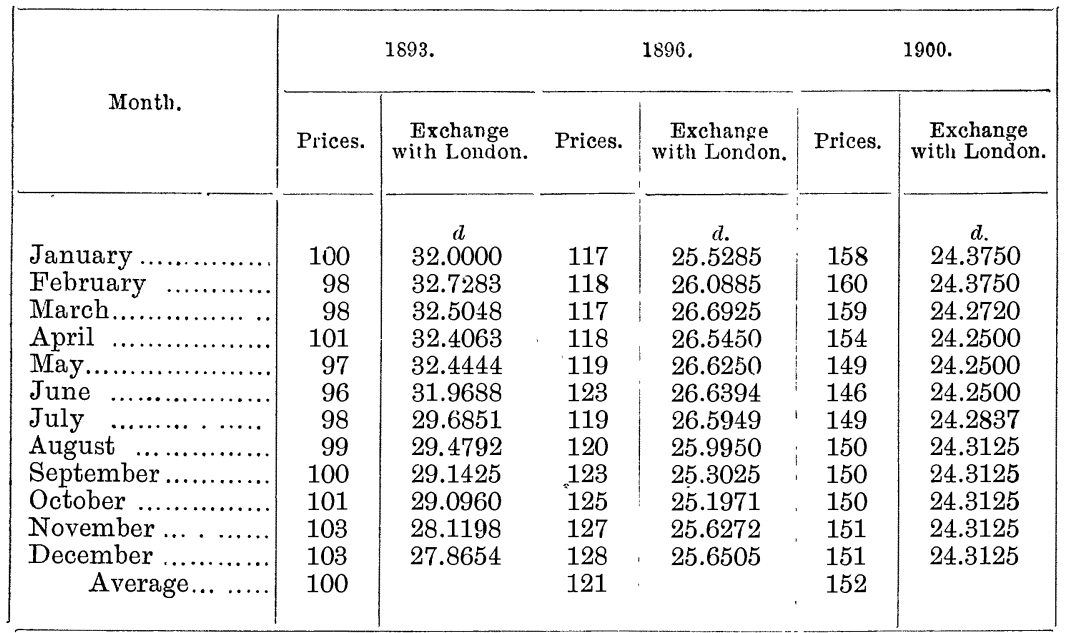

The relation between the chief money markets abroad has been made closer, and great saving has been effected in the gold payments abroad. Although it cannot be said that the rise of prices is solely due to the increase of the currency, it must be admitted that there is some relation between the two.

\begin{tabular}{|c|c|c|c|c|}
\hline Year. & Srecie. & Notes. & Total. & $\begin{array}{c}\text { Average of } \\
\text { prices. }\end{array}$ \\
\hline Dec. & Yen. & Yen. & Yen. & \\
1893 & $50,672,072$ & $187,826,247$ & $238,498,319$ & 100 \\
1894 & $62,711,242$ & $185,000,044$ & $247,711,286$ & 106 \\
1895 & $69,737,986$ & $212,262,825$ & $282,000,811$ & 112 \\
1896 & $76,185,729$ & $224,187,957$ & $300,373,686$ & 121 \\
1897 & $91,765,257$ & $238,704,885$ & $330,470,142$ & 134 \\
1898 & $80,941,508$ & $204,678,190$ & $285,619,698$ & 142 \\
1899 & $82,140,051$ & $254,687,822$ & $336,827,874$ & 142 \\
1900 & $89,460,356$ & $228,570,032$ & $318,030,388$ & 152 \\
& & & & \\
\hline
\end{tabular}

\section{1Present State of Finance and Economy.}

Although the financial scheme for 1901-1902 was adopted by the Parliament, and increase in taxes was assented to, the whole amount of taxes could not be realized at once. Neither is it easy now to raise loans at home or abroad, and the Chinese indemnity could not be made use of much longer. The lending power of the Bank of Japan was curtailed by the decrease of its issuing power on account of the efflux of

1 The Editors regret that they are compelled, by want of space, to omit two sections dealing with the growth of Trade and Industry and the improvement in means of communication. 
gold. Thus, although the financial recovery of the country is very far from being hopeless, yet it is temporarily obstructed. The Finance Minister of the Ito Cabinet brought forward a scheme for postponing Government works for a few years, just after the close of the session. This was opposed by many Ministers, on the ground that it could be avoided if the Treasury try to skilfully manipulate various items. The Finance Minister, on the other hand, urged strongly the mistake of the hand-to-mouth policy hitherto adopted, as it causes endless increase of expenditure, and national debt, as well as the disturbance of the money market. Marquis Ito tendered his resignation in May, on the ground of his inability to preserve harmony among the Ministers of the State. Whoever may take up the reins of the Government, and have the key of the National Treasury, the futility of the hand-to-mouth policy urged by the post bellum buoyancy must be admitted, and there are many who advocate the views entertained by the ex-Finance Minister. But this is no proof that the Imperial Treasury is really in difficulty. It is merely a question of management and appearance. For instance, in the fiscal years which were spoken about as to be most hard to tide over, a large surplus accrued in the actual account.

\begin{tabular}{|c|c|c|}
\hline & 1898-1899. & $1899-1900$. \\
\hline 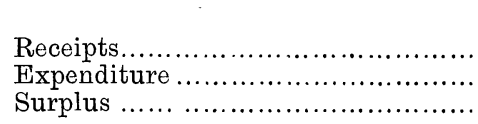 & $\begin{array}{r}\text { Yen. } \\
121,440,000 \\
120,580,000 \\
860,000\end{array}$ & $\begin{array}{r}\text { Yen. } \\
178,550,000 \\
140,510,000 \\
38,040,000\end{array}$ \\
\hline
\end{tabular}

On the side of the general market also, in contrast to the brisk state that followed the successful outcome of the war with China, there has set in a bad time. Low price, high interest, and bankruptcies appeared in the field, with some symptoms of panics among banks. The blow has been aggravated by the decline of the Chinese trade due to the delay of the restoration of the normal state in Peking. Everyone complains of depression and dearth of money. The country seems to be attacked by a sense of fear and anxiety, being just the reverse of the prevalence of universal enterprising spirit in years following 1894. Banks are on the lookout, traders refrain from new undertakings, and the public go for abstinence. But the symptoms are on the better side, prices falling, ${ }^{1}$ balance of trade becoming favourable, speculation cooling down, and sound, steady habits gaining ground in the business circle.

1 If prices index for May be compared with that of April, there is a fall of little over 2 per cent. 


\section{Remedy Proposed.}

Many plans for remedy of the present state of finance and economy are brought forward. The most prevalent for economical distress are :-

1. Importation of foreign capital.

2. Purchase by the State of private railways.

3. Redemption of national debt.

4. Thrift and saving.

5. Contraction of the note issue of the Bank of Japan.

For financial difficulty the remedies proposed are:

6. Loans raised abroad.

7. Increase of taxes.

8. Drastic retrenchment in every direction.

Even granting that foreign capital and loans [(1) and (6)] are desirable, investment must be encouraged among foreign capitalists, which may take some time. The State purchase of railways and national debt redemption [(2) and (3)] want funds, which are the very thing now in need. Moreover, if suddenly a great sum be imported from outside and scattered at random, such evils as high price, excess of importation, efflux of gold, and another dearth of money will be repeated, leaving only the increased burden of debt. Though thrift and saving (4) are matters of self-evident necessity at any time, and may be of use for discouraging luxurious habits prevalent after the war, they may not give immediately any positive helps. The over issue and expansion of currency (5) are no doubt very deplorable; yet if contraction be suddenly and artificially executed, it may cause damages. There may arise necessity for more taxes (7), but it may be better to leave room for future emergency, especially after a repeated increase of taxation within so short a space of time. The only remaining remedy, retrenchment (8), is above all advisable. Since the war, the military and naval expenditure have thus increased gradually.

\begin{tabular}{|c|c|c|}
\hline & $1895-1896$. & $1901-1902$ \\
\hline 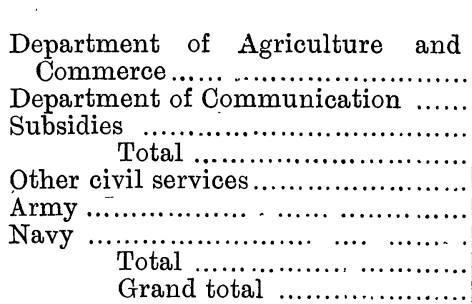 & $\begin{array}{r}\text { Yen } \\
1,235,719 \\
\\
8,468,566 \\
1,274,648 \\
10,978,933 \\
50,802,045 \\
10,015,933 \\
13,520,268 \\
23,536,201 \\
85,317,179\end{array}$ & $\begin{array}{r}\text { Yen. } \\
10,705,060 \\
\\
50,789,205 \\
2,023,495 \\
63,517,760 \\
100,970,402 \\
50,114,785 \\
38,330,423 \\
88,445,208 \\
252,933,370\end{array}$ \\
\hline
\end{tabular}

Although it is undesirable to cut down expenses without any distinction whatsoever, much could be saved if thorough economy be 
carried out in all departments of the State. Indeed, the money market and general economy were disturbed and injured by the too rapid increase of Government undertakings, especially by the sudden demand for labour and goods called forth by the army extension. The financing by the Chinese indemnity and sterling loans drove the economic movement from its normal track. If left alone, the rise of prices will cause excess of importation and efflux of specie, which in turn will bring fall of prices and increase of exportation, the evil thus correcting itself. But, in order to avoid the loss of specie, moneys invested in London, such as Chinese indemnity and loans issued, were made use of. Consequently, although excess of importation ensued, prices did not fall, and exportation was somewhat discouraged.

\section{Concluding Remarks.}

To conclude, as regards general economy, it is best to leave things to themselves. If, on the contrary, artificial remedies as above mentioned are resorted to, the disturbances will be repeated, and the healing of the wound will only be delayed. As regards the public finance, although economy in all departments is necessary, expenses for productive purposes must not be grudged, while those which are unproductive may greatly be cut down. In economy and finance one-sided drastic and extreme views must be avoided. Vacillation is harmful, but neither are sudden changes advisable. If properly managed, the economic strength of the country, which is not only very far from being exhausted, but is just in its youthful development, will show its true value. The gloom will pass away and things will become brighter.

Some of the Russian papers apprehend that " the Japanese frog will burst itself by trying to appear large." The simile is simply absurd. She is just in the growing stage, therefore if she becomes larger it is by natural growth, and her economic development is not as quick as might be, because of the deficiency of nourishing capital. When once the due amount of capital is properly supplied, first from the savings of her own people, and then from the far-seeing foreign capitalists, the progress of Japan will be much accelerated, to the mutual advantage of herself and her creditors. It is a great misfortune for Japan that her real strength is not duly known and fully admitted by the world at large. In the art of war she showed it amply, in the Chino-Japanese war and the Boxers' affair. Now it remains for her to prove that her capacity and ability are not inferior to her fighting power, on which she is now beginning to find out that too much stress was laid. If judgment, prudence, and patience be well exercised hereafter, a bright future lies before her in the peaceful works of commercial and industrial progress, for which she possesses many natural advantages.

JIUCHI SOYEDA,

Correspondent for Japan to the British

Economic Association 